interstices of social order," remain elusive. Individual practitioners, pupillages and segmentary lineages differ widely in their ability to maintain their status "at the terminus of civilization," in the world but not of the world. Taylor's detached perspective on the subjects of his study may be necessitated by respect for his informants, who justifiably fear excessive publicity and the risk of "spoiling," but this perspective gives the work its theoretical flavor, despite the attention to detail. It is widely believed that Ajaan Man, in life "an enigma to the authorities," attained release from the conventional world and entered "nipphaan" (nirvana) upon his death in 1949. His ultimate release coincided with a surge of national attention for "the old 'vagabond' monk" and "infusion into the stream of orthodoxy." A compelling image of Man, as "arahan" (saint), is the still core of this book. For the reader, this book is his jedii. The irony is that he cannot be eulogized without it.

\title{
Women and Change in the Caribbean, edited by Janet $H$. Momsen. Kingston: Ian Randle; Bloomington: Indiana University Press; London: Currey, 1993. x, 320 pp.
}

\section{Reviewed by Marietta Morrissey, Professor and Chair, Department of Sociology, Anthropology, and Social Work, University of Toledo, Toledo, Ohio.}

The study of women and gender in the Caribbean has quickly expanded as major works have appeared on women in slavery, in late nineteenth and twentieth century free labor forces, and in contemporary politics and economy. The Caribbean is particularly intriguing to scholars of women and gender because of Caribbean women's historically significant roles in both the economy and the domestic sphere. Moreover, women's position differs among Caribbean societies, both across major language groups (the English, Spanish, and French-speaking West Indies) and within geographically and culturally defined areas.

It is challenging to capture the range of current research and theorizing on women in the Caribbean. Janet Momsen manages to do so, however, offering a comprehensive and exciting synthesis of recent scholarship in her anthology, Women and Change in the Caribbean. Momsen is a well known geographer with extensive research experience in the eastern Caribbean. She presents eighteen articles on women's work and status in various Caribbean nations, all focusing on the contemporary era, but with many discussing Caribbean women's history as well. As Momsen suggests in her thoughtful introduction, the collection is valuable for its pan-Caribbean and multidisciplinary focus and strong base in field work. The authors criticize several traditional theoretical paradigms, including the presumed dichotomy between women's public and private roles. They offer alternative perspectives that stress women's multiple and intersecting roles and the constant interaction of race, class, and gender throughout Caribbean history. Momsen divides the articles into two major sections, one, on private and public spheres, and the second on women's economic roles.

The first section explores the relationship of women's work in production and reproduction and the intersection of domestic and community-level activities. Two essays are critical of traditional conceptual approaches that lend little to our understanding of women in the Caribbean. Besson questions the utility of Peter Wilson's dualism of "reputation and responsibility" for the study of women, presenting research on a Jamaican 
peasant community to support her claims. Berleant-Schiller and Maurer explore the blending rather than the separation of women's private and public roles in Dominica and Barbuda. Several essays in this section consider important Caribbean institutions in new ways. Pulsipher's paper on houseyards in Monteserrat shows how men's and women's places in domestic networks are spatially represented in the yard and how these roles shift over the life cycle. Brana-Schute traces the recent history of women's groups in Suriname, suggesting a mix of political and social functions, while raising questions about why women have not assumed more prominent and powerful political roles. Women's extensive obligations to kin, even after migrating, are explored by Olwig in an essay on women's intra-regional and international migration from Nevis.

The second half of the collection, on women in the economy, examines women's work in both rural and urban sectors. Contributions on women in rural economies generally point to women's historically extensive participation in farming. Papers on Barbados, Grenada, and Trinidad describe patterns of work, land control and crop selection. Stubbs' article on women's involvement in Cuban cooperative agriculture in relation to recent changes in political economy is especially interesting. Momsen's comparative analysis of women's farming and patterns of labor force participation in the eastern Caribbean also addresses structural economic changes in the region. Papers on women in the urban sector treat some new dimensions of women's work experience. Pearson's essay on gender and Jamaican information processing firms suggests that while national investment and control has increased industrial dynamism it will help women workers only if their technical abilities are acknowledged and easily transferred to better jobs. McKay's research on women and tourism in Negril, Jamaica, illustrates the constraints women marketers and landladies face from government regulation and from competition and control by men.

This collection is significant for its comprehensive scope and its rich empirical base. The second half of the book, on women in the economy, may be more successful in offering new information and ideas than the first, on the relationship of the public and private spheres. Momsen's Introduction and the precis to each section are acute; she could have offered further theoretical synthesis and more comparisons among societies without damaging the integrity of the empirical work. Essays on the English speaking West Indies significantly outnumber offerings on other areas. However, these problems do not diminish the value of the collection and its importance to the study of women and gender in the region.

\section{This Fissured Land: An Ecological History of India. Madhav Gadgil and Ramachandra Guha. Berkeley: University of California Press, 1992. xiv, 274 pp.}

\section{Reviewed by Sonja Brodt, Professor of Geography, University of Hawaii, Manoa Honolulu, HI 96822}

In a time of increasing polarity between North and South, first world and third world, over issues regarding natural resource use and management, Madhav Gadgil and Ramachandra Guha manage to move beyond the usual narrow, postcolonialist debates to construct a wider framework for analysis of Indian ecological problems in This Fissured Land: An Ecological History of India. Although not evident in the title, this book is 